Miami Nature Biotechnology Short Reports

TheScientificWorld (2001) 1 (S3), 97SR

ISSN 1532-2246; DOI 10.1100/tsw.2001.202

\title{
AFRICAN SWINE FEVER VIRUS (ASFV) MULTIGENE FAMILIES 360 AND 530 GENES PROMOTE INFECTED MACROPHAGE SURVIVAL
}

\author{
L. Zsak*, J.H. Sur, T.G. Burrage, J.G. Neilan, and D.L. Rock \\ Plum Island Animal Disease Center, USDA, ARS, P.O. Box 848, Greenport, NY 11944 \\ *lzsak@piadc.ars.usda.gov
}

INTRODUCTION. In the swine host ASFV infects cells of the mononuclear-phagocytic system including fixed tissue macrophages (1). Cytopathological changes consistent with apoptotic cell death, including karyorrhexis and chromatin condensation, have been observed in mononuclear cells in tissues of pigs infected with highly virulent ASFV isolates (2). ASFV infection induced apoptosis in primary swine macrophages in vitro at late time postinfection, a time at which viral replication had already occurred in these cells (3). Thus, transient modulation of infected macrophage survival may be necessary for productive viral replication to occur in this cell type.

METHOD. ASF viruses were grown in primary macrophage cell cultures as previously described (3). Trypan blue dye exclusion assay was used to determine cell viability; TUNEL assay and Cell Death Detection ELISA ${ }^{\text {plus }}$ kit were applied to detect apoptosis in infected cells.

RESULTS. In marker rescue and reverse genetics experiments we found that deletion of a 10kbp region from the left variable terminus of pathogenic ASFV genomes, containing six multigene family (MGF) 360 and two MGF 530 genes, markedly reduced viral growth in swine macrophage cell cultures. Cell viability studies and apoptosis assays revealed a significant reduction in survival time, and accelerated and increased apoptotic cell death in gene deletion mutant, $\Delta 35$-infected macrophage cell cultures (see Fig. 1).

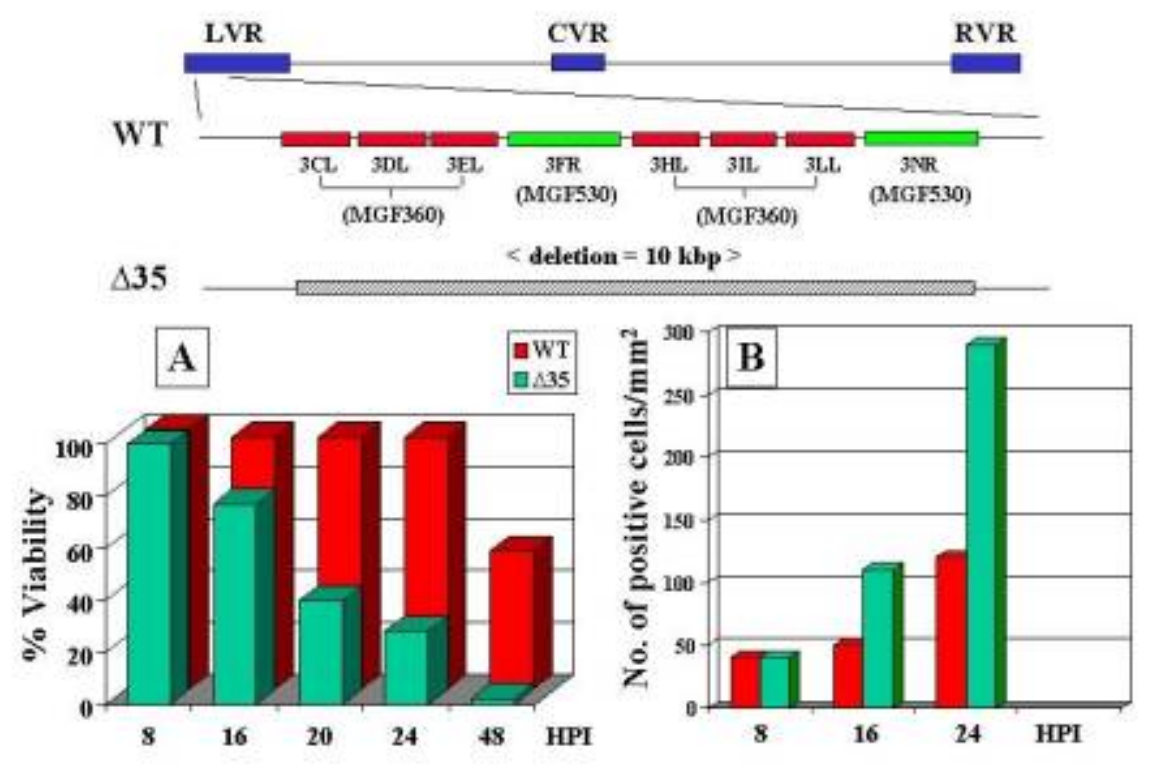


To examine gene function(s) in swine we have compared the pathogenesis of $\Delta 35$ infection to its revertant virus, $\Delta 35$-R. In contrast to $\Delta 35$-R-infected pigs, where $100 \%$ of the animals died within 10 days postinfection, all $\Delta 35$-infected pigs survived infection. Virus titers in lymphoid tissues, lung, and liver were significantly reduced by 100-10,000-fold over revertant virus values. Immunohistochemistry showed a markedly reduced number of $\Delta 35$-infected cells in those tissues; however, a significantly increased rate of apoptotic cell death was observed when compared to $\Delta 35-\mathrm{R}$ at 3 days postinfection.

DISCUSSION. Our data indicate that ASFV MGF 360 and MGF 530 genes perform an essential macrophage host range function(s) that involves the promotion of infected cell survival. Reduced viral growth in macrophages together with increased early apoptotic death of virus-infected cells likely account for the attenuation of $\Delta 35$ in swine.

ACKNOWLEDGEMENT. We thank Aniko Zsak and the PIADC animal care staff for excellent technical assistance.

\section{REFERENCES.}

1. Mebus, C.A. (1988) Adv. Virus Res. 35, 251-269

2. Colgrove, G.S., Haelterman, E.O., and Coggins, L. (1969) Am. J. Vet. Res. 30, 1343-1359

3. Neilan, J.G., Lu, Z., Kutish, G.F., Zsak, L., Burrage, T.G., Borca, M.V., Carrillo, C., and Rock, D.L. (1997) Virology 230, 252-264 

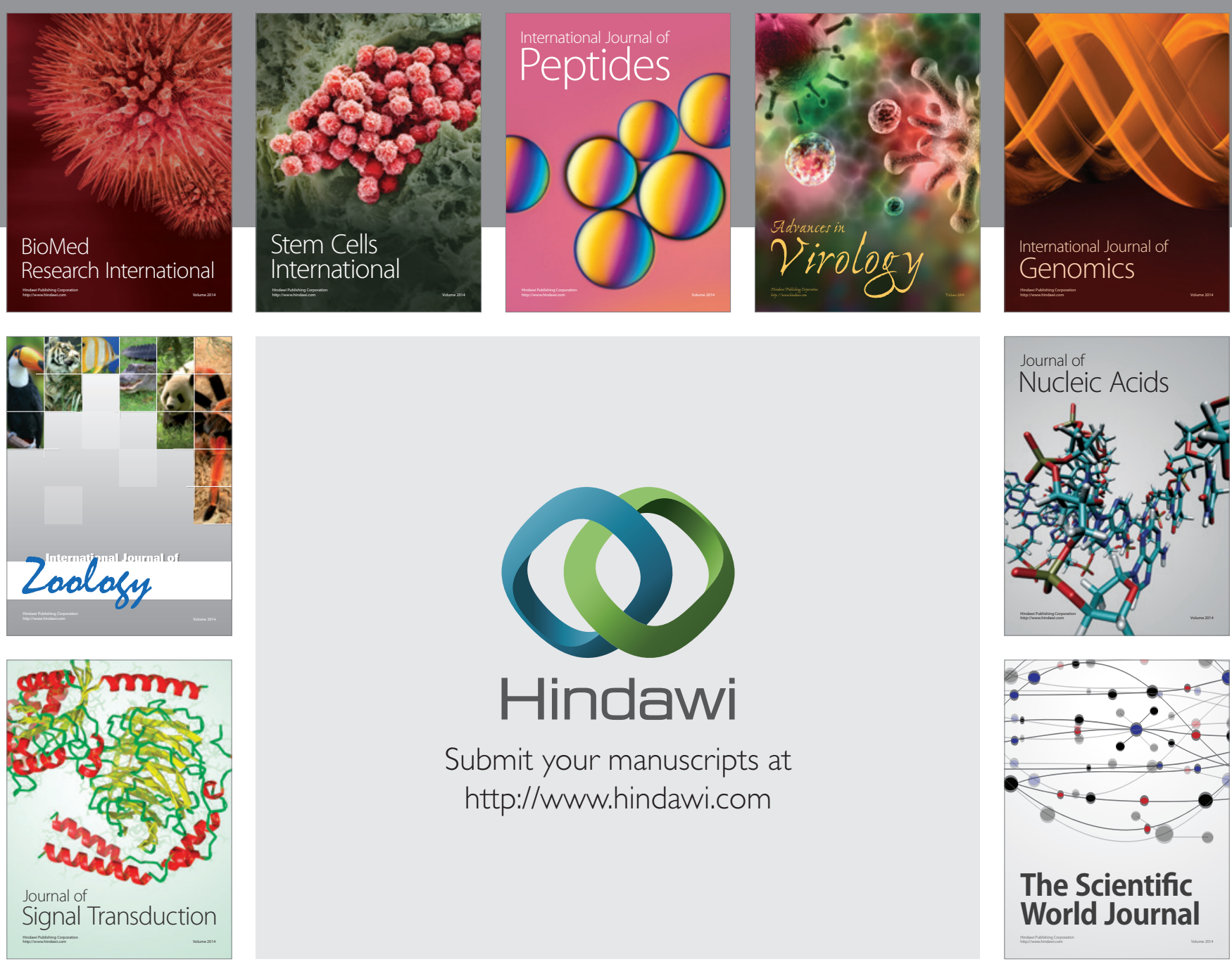

Submit your manuscripts at

http://www.hindawi.com
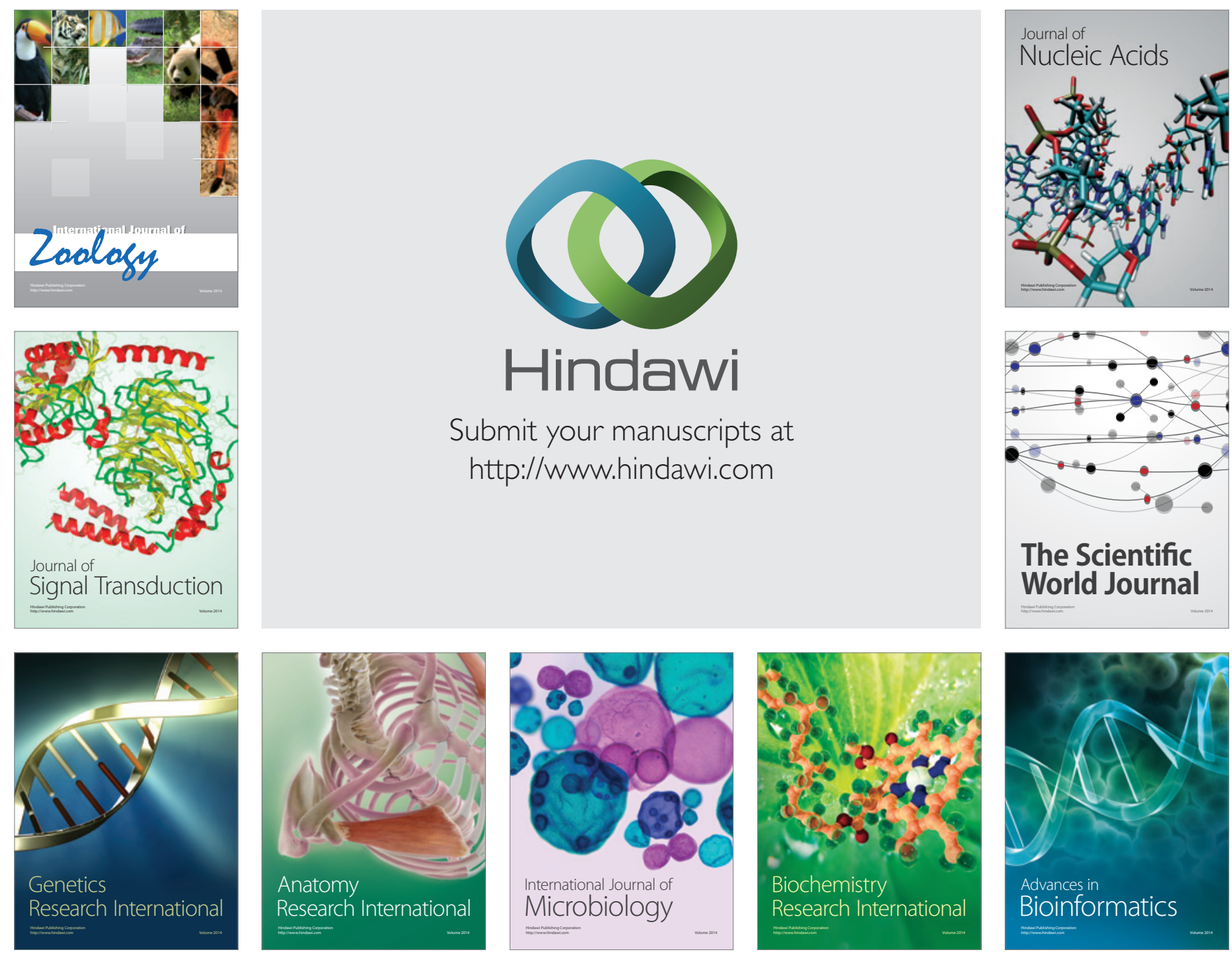

The Scientific World Journal
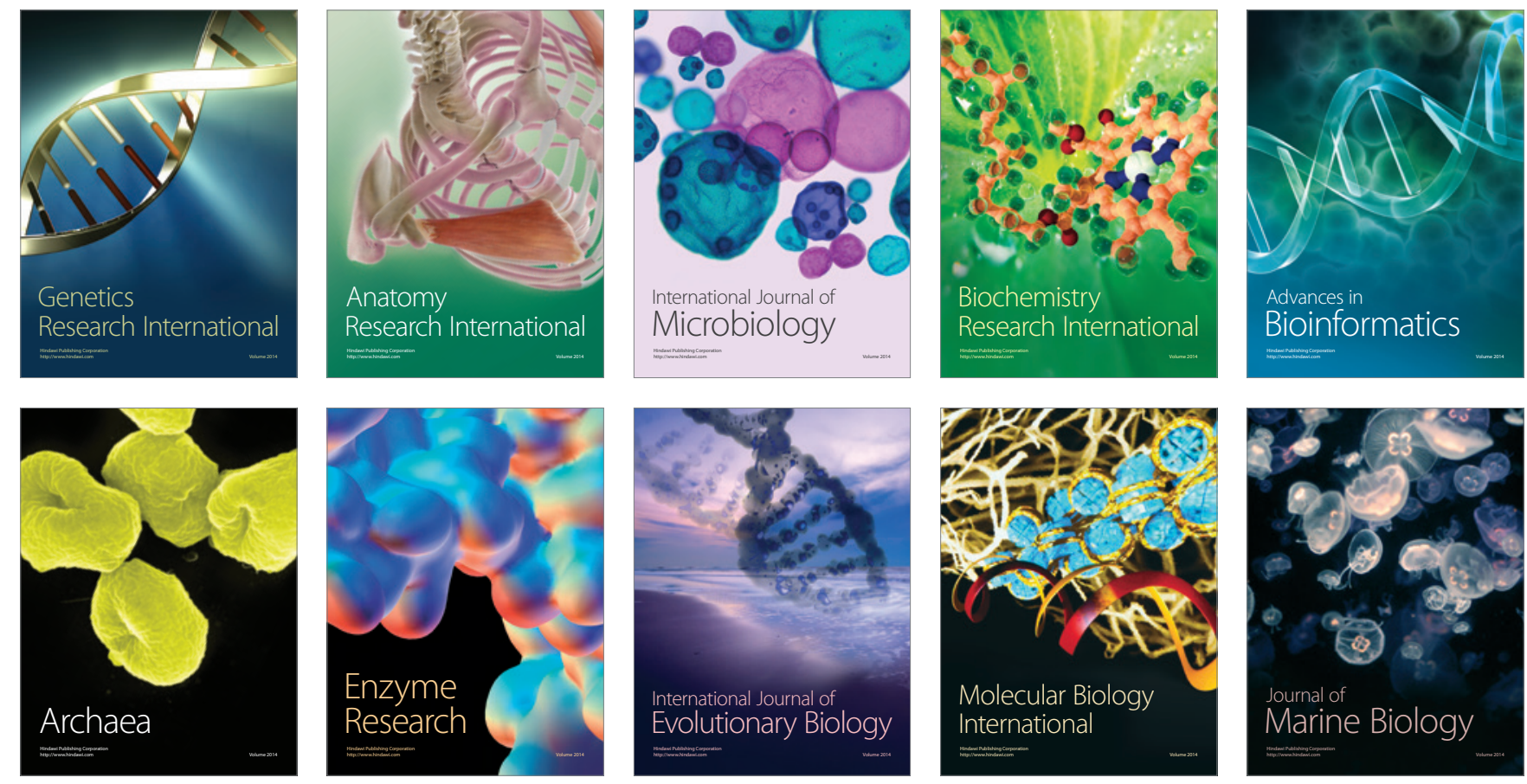